\title{
A New Family of Bimetallic Framework Materials Showing Reversible Structural Transformations
}

\author{
Olha Sereda, ${ }^{\dagger}$ Fritz Stoeckli,${ }^{\dagger}$ Helen Stoeckli-Evans, ${ }^{* \dagger}{ }^{\dagger}$ Oleg Dolomanov,${ }^{\ddagger}$ \\ Yaroslav Filinchuk, ${ }^{\S}$ and Phil Pattison ${ }^{\S, \|}$ \\ Institute of Physics, University of Neuchâtel, rue Emile-Argand 11, CH-2009 Neuchâtel, Switzerland, \\ Department of Chemistry, Durham University, Durham, DH1 3LE, U.K., Swiss Norwegian Beamlines \\ at ESRF, BP-220, 38043 Grenoble, France, and Laboratoire de Crystallographie, École Polytechnique \\ Fédérale de Lausanne, BSP, CH-1015 Lausanne, Switzerland
}

Received August 11, 2008; Revised Manuscript Received April 24, 2009

\begin{abstract}
Three new bimetallic framework compounds, namely, $\left(\left(\left[\mathrm{Cd}_{3}(\mathrm{tn})_{4}\right]\left[\mathrm{Co}(\mathrm{CN})_{6}\right]_{2}\right) \cdot 5 \mathrm{H}_{2} \mathrm{O}\right)_{\infty}(\mathbf{1}),\left([\mathrm{Cd}(\mathrm{tn})]_{3}\left[\mathrm{Cr}(\mathrm{CN})_{6}\right]_{2}\right)_{\infty}$ (2), and $\left(\left[\mathrm{Cu}_{2}(\mathrm{tn})_{2}\right]\left[\mathrm{Ru}(\mathrm{CN})_{6}\right] \cdot 4 \mathrm{H}_{2} \mathrm{O}\right)_{\infty}(3)$, have been prepared in a very simple manner from the ligand 1,3-diaminopropane (tn),

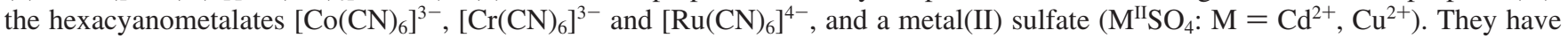
been characterized by IR, X-ray diffraction, elemental analysis and immersion calorimetry. All three compounds have three-dimensional structures, with both the organic ligand and the cyanide groups acting as bridges. Compounds $\mathbf{1}$ and $\mathbf{3}$ have channels occupied by water molecules of crystallization. All three complexes are stable indefinitely when exposed to the air at room temperature; however, when compounds $\mathbf{1}$ and $\mathbf{3}$ are heated, they lose the water molecules of crystallization. The powder X-ray diffractograms of these dried and as yet unknown species are different from those of the original compounds. However, in a humid atmosphere both dried compounds readsorb water molecules and revert to the original structures, as shown by powder X-ray diffraction measurements. The adsorption properties of compounds $\mathbf{1}$ and $\mathbf{3}$ were studied using immersion calorimetry and in situ powder X-ray diffraction. In the case of compound 3 the heat of the structural transformation on rehydration was found to be ca. $19 \pm 3 \mathrm{~J} / \mathrm{g}$.
\end{abstract}

\section{Introduction}

The domain of three-dimensional coordination polymers, or metal-organic frameworks (MOFs) as they are called today, is an intensely studied field of research, and the subject has been reviewed recently by various authors who are extremely active in this field. ${ }^{1-8}$ These compounds are of great interest owing to their potential applications in the areas of gas storage, gas separation, and heterogeneous catalysis. ${ }^{9-22}$ The majority of these compounds are homometallic and have been formed using organic carboxylates and transition metal salts. ${ }^{23-28}$ Some cyanide-bridged inorganic coordination polymers, prepared by assembling cyanometalate anions and transition metal complexes as building blocks, have also been found to have framework structures. The hexacyanometalates, $\mathrm{M}^{\mathrm{II}}(\mathrm{CN})_{6}{ }^{4-}$ and $\mathrm{M}^{\mathrm{III}}(\mathrm{CN})_{6}{ }^{3-}$, are good building blocks, and a number of multidimensional systems have been synthesized, some with interesting magnetic properties. $^{29-34}$ Interest in the gas sorption properties of these compounds has increased in recent years. ${ }^{35}$ However, only a small number of coordination polymers based on hexacyanometalates have been reported as being porous. ${ }^{36,37}$ Porous materials that show reversible phase transformations on loss and addition of solvent molecules have also been reported on recently. ${ }^{38-41}$

We have focused our efforts on the synthesis of crystalline materials, since the attainment of well-defined structures is intimately linked to an understanding of the design, synthesis and properties of such materials. For example, using hexacyanochromate(III) it was possible to prepare bimetallic threedimensional (3D) and chiral one-dimensional (1D) metal-organic

* Corresponding author. Mailing address: Institut de Physique, Université de Neuchâtel, Rue Emile-Argand 11, CH-2009 Neuchâtel, Switzerland. E-mail: Helen.Stoeckli-Evans@unine.ch.

University of Neuchâtel.

* Durham University.

Swiss Norwegian Beamlines at ESRF.

"École Polytechnique Fédérale de Lausanne. cyano-bridged materials which exhibit ferromagnetism. ${ }^{42}$ In another case, we have successfully prepared a bimetallic 3D metal-organic cyano-bridged framework material using $4,4^{\prime}$ bipyridine, tetracyanonickelate and copper sulfate. ${ }^{43}$

Our interests are in the construction of materials, porous or not, in which such phase transformations take place. ${ }^{44}$ Here we report on three new 3D metal-organic cyano-bridged frameworks, prepared in a very simple manner from the ligand 1,3diaminopropane $(\mathrm{tn})$, the hexacyanometalates $\left[\mathrm{Co}(\mathrm{CN})_{6}\right]^{3-}$, $\left[\mathrm{Cr}(\mathrm{CN})_{6}\right]^{3-}$ and $\left[\mathrm{Ru}(\mathrm{CN})_{6}\right]^{4-}$, and a metal(II) sulfate $\left(\mathrm{M}^{\mathrm{II}} \mathrm{SO}_{4}\right.$ : $\left.\mathrm{M}=\mathrm{Cd}^{2+}, \mathrm{Cu}^{2+}\right)$. In order to explore their potential adsorptive properties and to study the various phase transformations that take place, the techniques of immersion calorimetry and in situ powder X-ray diffraction have been used.

\section{Experimental Section}

Elemental analyses of carbon, hydrogen, and nitrogen were performed by the Microanalysis Service of the Laboratory of Pharmaceutical and Organical Propedeutical Chemistry at the University of Geneva (Geneva, Switzerland). Infrared spectra were measured using $\mathrm{KBr}$ pellets in the interval of $4000-40 \mathrm{~cm}^{-1}$ using a Perkin-Elmer $1720 \mathrm{X}$ FT-IR spectrometer. Thermogravimetric (TG) analyses were carried out using a Mettler 4000 module. Samples were introduced in a closed aluminum oxide crucible and heated at rate $0.1^{\circ} \mathrm{C} \mathrm{min}{ }^{-1}$ under nitrogen at atmospheric pressure. DSC measurements were done with a modified differential scanning calorimeter (Mettler Toledo DSC 822e), under $\mathrm{N}_{2} / \mathrm{He}$ at a rate of $1{ }^{\circ} \mathrm{C} / \mathrm{min}$. Immersion calorimetry experiments were carried out at $293 \mathrm{~K}$ on samples of $0.15-0.20 \mathrm{~g}$ using a TIAN-CALVET type calorimeter. ${ }^{45,46}$ The outgassed sample was placed in the calorimetric cell which was then immersed into a water bath controlled by a thermoregulator system LUDA MS. The thermal flow was provided by 180 thermocouples of $\mathrm{Cu} /$ constantan connected to a nanovoltmeter PREMA 8017. The integral of the curve, $V=f(t)$, is proportional to the energy generated during the immersion process, $\Delta_{\mathrm{i}} H$. The normal calibration of the calorimetry system was carried out with an electrical resistance. The accuracy varies between 4 and 5\% depending on the absolute energy liberated in the process and on the amount of solid used. 
General Synthetic Procedures. Single crystals of compounds 1 and 2 were obtained only when the nonstoichiometric ratios of $\mathrm{Cd}(\mathrm{II})$ with $\mathrm{M}$ (III) cyanides were used. Use of the standard reaction ratios, 3:2 or $2: 1$, always resulted in the precipitation of insoluble powders.

(a) $\left(\left(\left[\mathbf{C d}_{3}(\operatorname{tn})_{4}\right]\left[\mathbf{C o}(\mathbf{C N})_{6}\right]_{2}\right) \cdot \mathbf{5 H}_{2} \mathbf{O}\right)_{\infty}(\mathbf{1})$. To a solution of tn $(0.220$ $\mathrm{mL}, 2 \mathrm{mmol})$ and $\mathrm{CdSO}_{4}(0.312 \mathrm{~g}, 1 \mathrm{mmol})$ in $30 \mathrm{~mL}$ of water, an aqueous solution of the $\mathrm{K}_{3}\left[\mathrm{Co}(\mathrm{CN})_{6}\right](0.332 \mathrm{~g}, 1 \mathrm{mmol})$ was added dropwise. The reaction mixture was stirred for $30 \mathrm{~min}$, and then $\mathrm{NaClO}_{4}$ $(0.12 \mathrm{~g}, 1 \mathrm{mmol})$ was added to aid crystallization. After stirring and heating at $75{ }^{\circ} \mathrm{C}$ for a few minutes, the mixture was filtered. Light yellow square-shaped crystals of compound $\mathbf{1}$ appeared from the filtrate after some days, yield of $0.13 \mathrm{~g}(39 \%)$. Elemental analysis: found $\mathrm{C}$, 25.05; $\mathrm{H}, 4.26 ; \mathrm{N}, 24.50 ; \mathrm{C}_{24} \mathrm{H}_{52} \mathrm{~N}_{20} \mathrm{Cd}_{3} \mathrm{Co}_{2} \mathrm{O}_{5}$ requires $\mathrm{C}, 24.94 ; \mathrm{H}$, $4.53 \mathrm{~N}, 24.24 \%$.

(b) $\left([\mathbf{C d}(\mathbf{t n})]_{3}\left[\mathbf{C r}(\mathbf{C N})_{6}\right]_{2}\right)_{\infty}(\mathbf{2})$. To a solution of th $(0.220 \mathrm{~mL}, 2$ $\mathrm{mmol})$ and $\mathrm{CdSO}_{4}(0.312 \mathrm{~g}, 1 \mathrm{mmol})$ in $30 \mathrm{~mL}$ of water, an aqueous solution of the $\left.\mathrm{K}_{3}[\mathrm{CrCN})_{6}\right](0.332 \mathrm{~g}, 1 \mathrm{mmol})$ was added dropwise. The reaction mixture was stirred for $30 \mathrm{~min}$, and then $\mathrm{NaClO}_{4}(0.12 \mathrm{~g}$, $1 \mathrm{mmol}$ ) was added to aid crystallization. After stirring and heating at $75^{\circ} \mathrm{C}$ for a few minutes, the mixture was filtered. Light yellow squareshaped crystals of compound $\mathbf{2}$ appeared from the filtrate after some days, yield of $0.14 \mathrm{~g}(42 \%)$. Elemental analysis: found: C, 27.10; $\mathrm{H}$, 2.78; N, 26.31; $\mathrm{C}_{24} \mathrm{H}_{30} \mathrm{Cd}_{3} \mathrm{Cr}_{2} \mathrm{~N}_{20}$ requires $\mathrm{C}, 27.72 ; \mathrm{H}, 2.91 \mathrm{~N}, 26.94 \%$.

(c) $\left(\left[\mathrm{Cu}_{2}(\operatorname{tn})_{2}\right]\left[\mathbf{R u}(\mathbf{C N})_{6}\right] \cdot \mathbf{4} \mathbf{H}_{2} \mathbf{O}\right)_{\infty}(3) .1,3$-Diaminopropane $(1.0 \mathrm{~mL}$, $12.0 \mathrm{mmol}$ ) was added under aerobic conditions to a concentrated aqueous solution $(5 \mathrm{~mL})$ of $\mathrm{CuCl}_{2} \cdot 2 \mathrm{H} 2 \mathrm{O}(2.05 \mathrm{~g}, 12.0 \mathrm{mmol})$ with continuous stirring, leading to the immediate precipitation of a green powder. An aqueous solution of $\mathrm{Et}_{4} \mathrm{NOH}(0.52 \mathrm{~g}, 3.5 \mathrm{mmol})$ was then added to dissolve this precipitate, and the resulting dark-blue solution obtained was warmed (at ca. $60{ }^{\circ} \mathrm{C}$ for about $5 \mathrm{~min}$ ) and then filtered in order to remove the small amount of precipitate that remained. An aqueous solution $(20 \mathrm{~mL})$ of $\mathrm{K}_{4}\left[\mathrm{Ru}(\mathrm{CN})_{6}\right](2.47 \mathrm{~g}$, $6.0 \mathrm{mmol})$ was then added with continuous stirring. Slow concentration of the resulting solution at room temperature afforded prismatic green crystals of $\mathbf{3}$, which were filtered off and air-dried, yield of $0.92 \mathrm{~g} \mathrm{(27.4 \% ).} \mathrm{Elemental}$ analysis: found $\mathrm{C}, 23.39 ; \mathrm{H}, 4.43 ; \mathrm{N}, 22.86 ; \mathrm{C}_{12} \mathrm{H}_{28} \mathrm{~N}_{10} \mathrm{Cu}_{2} \mathrm{Ru}_{1} \mathrm{O}_{4}$ requires $\mathrm{C}, 23.84 ; \mathrm{H}, 4.67 ; \mathrm{N}, 23.17 \%$.

X-ray Structural Determination. A yellow crystal of $\mathbf{1}(0.5 \times 0.5$ $\times 0.5)$, a yellow crystal of $2(0.50 \times 0.50 \times 0.50)$ and a green crystal of $\mathbf{3}(0.40 \times 0.30 \times 0.30)$ were mounted on a Stoe IPDS II Image Plate Diffractometer System ${ }^{47}$ equipped with a graphite-monochromator; $\mathrm{Mo} \mathrm{K} \alpha$ radiation $(\lambda=0.71073 \AA$ ). Data collections were performed at $173 \mathrm{~K}$. The structures were solved by direct methods using the program SHELXS-97 ${ }^{48}$ and refined by full matrix least-squares on $F^{2}$ with SHELXL-97. ${ }^{48}$ The tn ligand is disordered in $\mathbf{3}$. The hydrogen atoms were included in calculated positions and treated as riding atoms. In general the water $\mathrm{H}$ atoms were refined with distance restraints. Further crystallographic and refinement details are given in Table 1.

Topological Analyses. The topological analyses of the 3D networks in compounds 1, $\mathbf{2}$ and $\mathbf{3}$ were carried out using the program OLEX. ${ }^{49}$ Full details are given in Table S1 of the Supporting Information.

X-ray Powder Diffraction. The powder samples were inserted in a glass capillary of $0.5 \mathrm{~mm}$ diameter. X-ray powder data were collected at room temperature on a computer controlled STOE STADI P focusing powder diffractometer ${ }^{50,51}$ equipped with a curved $\mathrm{Ge}(111)$ monochromator $\left(\mathrm{Cu} \mathrm{K \alpha} \alpha_{1} ; \lambda=1.54051 \AA\right)$. A STOE linear position sensitive detector was used. The compounds were measured in the range of $4^{\circ}$ $\leq 2 \theta \leq 90^{\circ}$ using a step width of $0.1^{\circ}$.

Variable Temperature Synchrotron Powder X-ray Diffraction. Variable temperature synchrotron powder diffraction measurements were carried out at the Swiss Norwegian Beamlines (BM01-A) using a MAR345 Image Plate detector, wavelength $=0.724312 \AA$, capillary to image plate distance $400 \mathrm{~mm}$, exposure times $60 \mathrm{~s}, 20^{\circ}$ oscillations about $\phi, 2 \theta$ limits $0-24^{\circ}$.

\section{Results and Discussion}

Crystal Structures. The crystal structure analysis of $\left(\left(\left[\mathrm{Cd}_{3}(\mathrm{tn})_{4}\right]\left[\mathrm{Co}(\mathrm{CN})_{6}\right]_{2}\right) \cdot 5 \mathrm{H}_{2} \mathrm{O}\right)_{\infty}(\mathbf{1})$ revealed that it is a threedimensional network with both th and cyanide bridges. The asymmetric unit consists of half a $\left[\mathrm{Co}(\mathrm{CN})_{6}\right]^{3-}$ anion, one and a half $[\mathrm{Cdtn}]^{2+}$ cations, and 2.5 water molecules (Figure 1). Atom $\mathrm{Cd} 2$ is located on a 2 -fold axis, while all the other atoms are at general positions.
Table 1. Crystallographic and Structure Refinement Data for 1, 2 and 3

\begin{tabular}{|c|c|c|c|}
\hline & 1 & 2 & 3 \\
\hline empirical formula & $\mathrm{C}_{24} \mathrm{H}_{50} \mathrm{~N}_{20} \mathrm{O}_{5} \mathrm{Cd}_{3} \mathrm{Co}_{2}$ & $\mathrm{C}_{24} \mathrm{H}_{40} \mathrm{~N}_{20} \mathrm{Cd}_{3} \mathrm{Cr}_{2}$ & $\mathrm{C}_{12} \mathrm{H}_{28} \mathrm{~N}_{10} \mathrm{O}_{4} \mathrm{Cu}_{2} \mathrm{Ru}$ \\
\hline formula mass & 1153.90 & 1049.96 & 604.59 \\
\hline wavelength $[\AA]$ & 0.71073 & 0.71073 & 0.71073 \\
\hline temperature $[\mathrm{K}]$ & 173 & 173 & 173 \\
\hline crystal system & monoclinic & triclinic & monoclinic \\
\hline space group & $C 2 / c$ & $P \overline{1}$ & $P 2_{1} / n$ \\
\hline$a(\AA)$ & 27.4141(15) & $7.7143(7)$ & $7.7882(10)$ \\
\hline$b(\AA)$ & $11.6135(6)$ & $7.8308(7)$ & $10.6489(17)$ \\
\hline$c(\AA)$ & $13.7184(9)$ & $16.1529(14)$ & $13.2933(16)$ \\
\hline$\alpha(\operatorname{deg})$ & 90 & $95.474(7)$ & 90 \\
\hline$\beta(\operatorname{deg})$ & $105.136(7)$ & $95.669(7)$ & $90.70(1)$ \\
\hline$\gamma(\operatorname{deg})$ & 90 & $91.569(7)$ & 90 \\
\hline volume $\left[\AA^{3}\right]$ & $4092.2(4)$ & $965.91(15)$ & $1102.4(3)$ \\
\hline$Z$ & 4 & 1 & 2 \\
\hline $\begin{array}{l}\text { calcd density } \\
{\left[\mathrm{g} / \mathrm{cm}^{3}\right]}\end{array}$ & 1.873 & 1.805 & 1.821 \\
\hline $\begin{array}{l}\text { absorption coeff } \\
{\left[\mathrm{mm}^{-1}\right]}\end{array}$ & 2.387 & 2.215 & 2.627 \\
\hline measured reflns & 21665 & 13543 & 8591 \\
\hline unique reflns $/ R_{\text {int }}$ & $5508 / 0.0184$ & $5137 / 0.0239$ & $2862 / 0.0275$ \\
\hline $\begin{array}{l}\text { obsd reflns } \\
{[I>2 \sigma(I)]}\end{array}$ & 5229 & 4981 & 2681 \\
\hline $\begin{array}{l}\text { no. of params } \\
\text { refnd }\end{array}$ & 261 & 251 & 182 \\
\hline$R_{1}^{a}[I>2 \sigma(I)]$ & 0.0153 & 0.0200 & 0.0365 \\
\hline $\mathrm{w} R_{2}^{b}[I>2 \sigma(I)]$ & 0.0344 & 0.0531 & 0.0990 \\
\hline
\end{tabular}

${ }^{a} R_{1}=\sum\left\|F_{\mathrm{o}}|-| F_{\mathrm{c}}\right\| / \sum\left|F_{\mathrm{o}}\right| .{ }^{b} \mathrm{w} R_{2}=\left[\sum w\left(F_{\mathrm{o}}{ }^{2}-F_{\mathrm{c}}{ }^{2}\right)^{2} / \sum w F_{\mathrm{o}}\right]^{1 / 2}$.

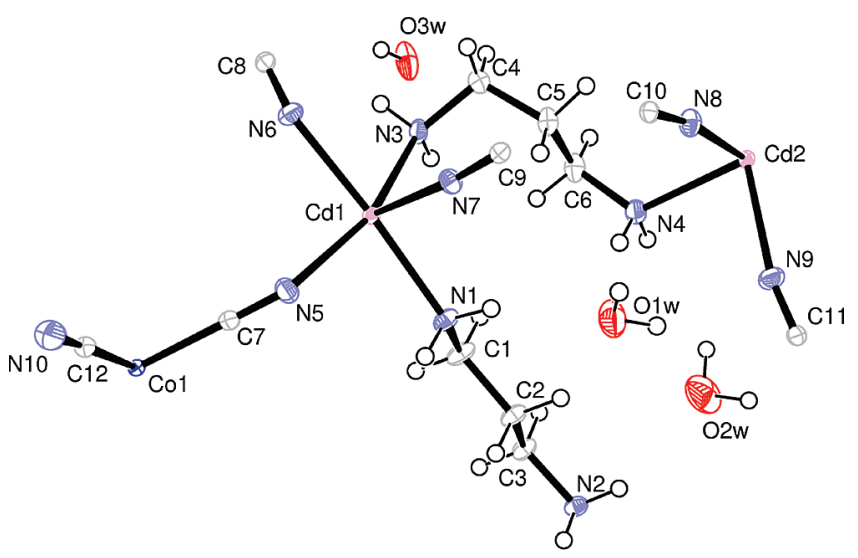

Figure 1. View of the asymmetric unit of 1, showing the atom numbering scheme and displacement ellipsoids drawn at the 50\% probability level.

Atom $\mathrm{Cd} 1$ is coordinated to three $\mathrm{N}$ atoms from tn ligands (one is bridging to $\mathrm{Cd} 2$ and the two others to $\mathrm{Cd} 1$ ) and three $\mathrm{N}$ atoms from the $\mathrm{CN}$ groups. Atom $\mathrm{Cd} 2$ also has an octahedral coordination, but is coordinated to only two $\mathrm{N}$ atoms from th ligands (bridged to $\mathrm{Cd} 1$ ) and four from $\mathrm{CN}$ groups. The bond distances and angles in the diamine skeletons are in the expected range [average values: $1.483(2) \AA$ for $\mathrm{N}-\mathrm{C}, 1.518(2) \AA$ for $\mathrm{C}-\mathrm{C}$, with bond angles of $123.02(11)^{\circ}$ for $\mathrm{Cd}-\mathrm{N}-\mathrm{C}$, and 114.05(14) for $\mathrm{C}-\mathrm{C}-\mathrm{C}]$; in good agreement with published work. ${ }^{52}$ The metal coordination environment of the hexacyanocobaltate(III) moiety is in good agreement with reported structures. ${ }^{53,54}$ The $\mathrm{Cd}-\mathrm{N}$ bond lengths vary from $2.318(2)$ to 2.416(2) A. Five of the six CN groups are bridging, while the sixth hydrogen bonds to water $\mathrm{O} 3 \mathrm{w}$ located in the channel (Figure 2a). Finally, it is worth noting the unusual bridging coordination mode of the th ligand, which leads to a $\mathrm{Cd} \cdots \mathrm{Cd}$ separation of 6.986(1) A. The structure can be described as being formed of hexa-metallocycles consisting of only $\mathrm{Cd}$ atoms and tn ligands, which are connected via cyano bridges to form a three-dimensional (3D) network (Figure 2a, top). 
a
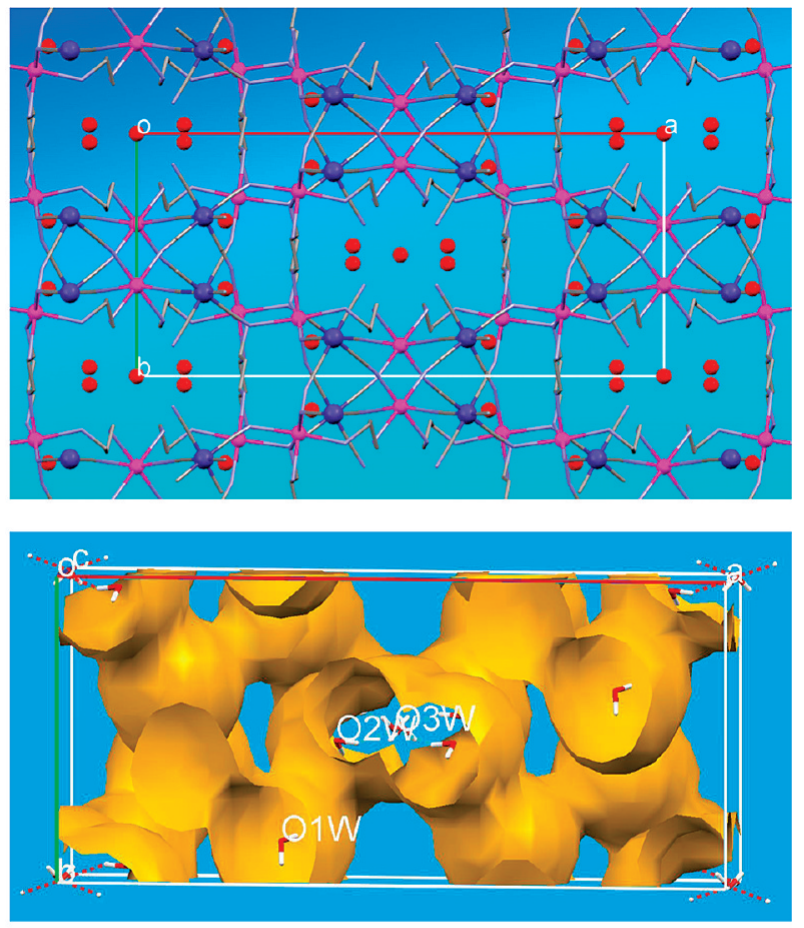

b

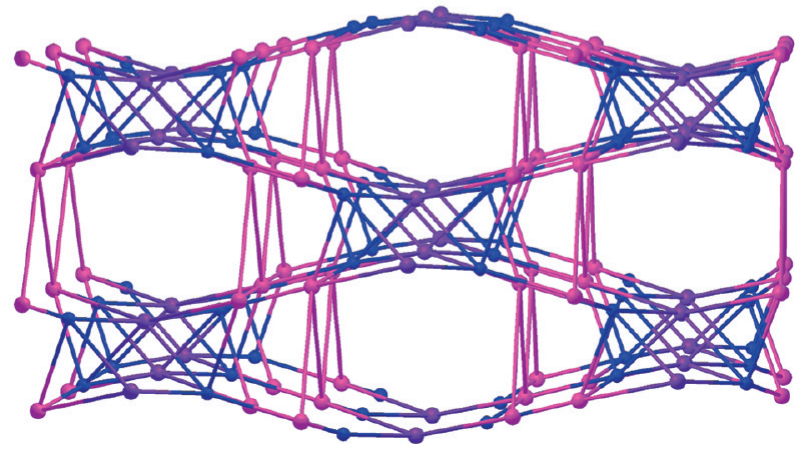

Figure 2. (a) Top: View down the $c$ axis of the crystal packing in $\mathbf{1}$. In the center can be seen the hexametallocycle, which is formed of $\mathrm{Cd}$ atoms (pink) bridged by tn ligands only. The water molecules in the cavities and channels are shown as red balls. The $\mathrm{H}$ atoms have been omitted for clarity. Bottom: A view down the $c$ axis of the framework surface, showing water molecule O1W occupying a cavity, and water molecules $\mathrm{O} 2 \mathrm{~W}$ and $\mathrm{O} 3 \mathrm{~W}$ occupying the channels. (b) View of a fragment of the topological network of $\mathbf{1}$ along the crystallographic $c$ direction. The $\mathrm{Co} 1$ atoms are shown in blue; $\mathrm{Cd} 1$, pink; $\mathrm{Cd} 2$, violet.

As shown in Figure 2a (bottom) water molecule $\mathrm{O} 1 \mathrm{~W}$ is situated in a small cavity, while water molecules $\mathrm{O} 2 \mathrm{~W}$ and $\mathrm{O} 3 \mathrm{~W}$ occupy channels (see also Figure S1 in the Supporting Information). They are hydrogen bonded to the terminal $\mathrm{CN}$ groups and the $\mathrm{NH}_{2}$ groups of the tn ligands (Table $\mathrm{S} 2$ in the Supporting Information). The potential solvent volume of $484.4 \AA^{3}$, occupied by the water molecules of crystallization, accounts for $11.8 \%$ of the volume of the unit cell $\left(4092.2 \AA^{3}\right) .{ }^{57}$

The topological analysis of $\mathbf{1}$ reveals a complex 3D extended framework structure, Figure $2 \mathrm{~b}$. The topological network has the $\left(3^{1} 4^{2} 5^{7} 6^{4} 7\right)_{2}\left(3^{1} 4^{4} 5^{5}\right)_{2}\left(3^{2} 4^{4} 5^{5} 6^{4}\right)$ Schläfli ${ }^{55,56}$ symbol for the 6-connected $\mathrm{Cd} 2$, 5-connected $\mathrm{Co} 1$, and 6-connected $\mathrm{Cd} 1$ nodes, respectively. The framework forms large hexagonal channels propagating in the crystallographic c direction (Figure 2b), which are filled by water molecules (cf. Figures $2 a$ and $2 b$ ).

The crystal structure analysis of $\left([\mathrm{Cd}(\mathrm{tn})]_{3}\left[\mathrm{Cr}(\mathrm{CN})_{6}\right]_{2}\right)_{\infty}(\mathbf{2})$ revealed that it is also a three-dimensional network with both

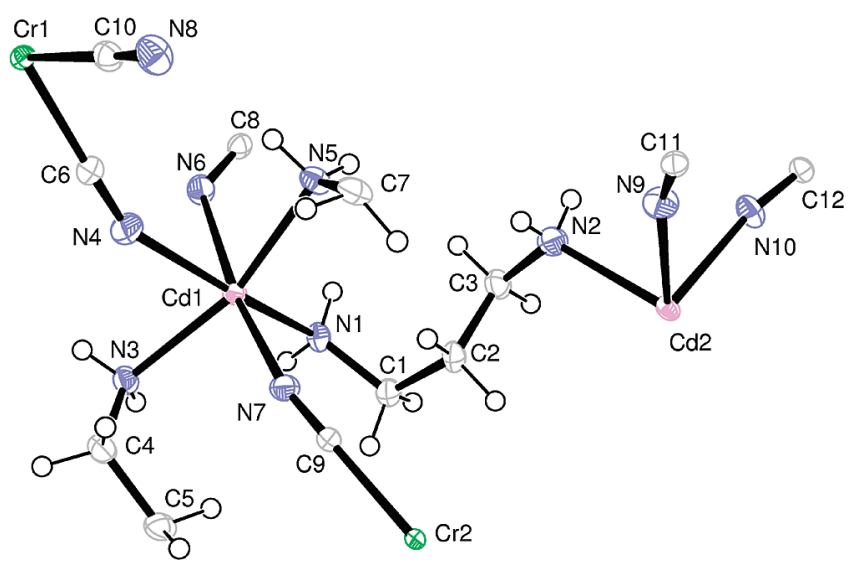

Figure 3. View of the asymmetric unit of 2, showing the atom numbering scheme and displacement ellipsoids drawn at the $50 \%$ probability level.

tn and cyano bridges. The asymmetric unit consists of two half $\left[\mathrm{Cr}(\mathrm{CN})_{6}\right]^{3-}$ anions and $1.5[\mathrm{Cd}(\mathrm{tn})]^{2+}$ cations (Figure 3).

The $\mathrm{Cr}$ atoms of the hexacyanochromate(III) anions, $\mathrm{Cr} 1$ and $\mathrm{Cr} 2$, are located on inversion centers. Atom $\mathrm{Cr} 1$ coordinates to three adjacent $[\mathrm{Cd} 1(\mathrm{tn})]^{2+}$ cations through four cyano nitrogens, while atom $\mathrm{Cr} 2$ coordinates to four adjacent $[\mathrm{Cd} 2(\mathrm{tn})]^{2+}$ cations. Each $\mathrm{Cr}^{\mathrm{III}}$ ion has almost regular octahedral coordination geometry. The $\mathrm{Cr}-\mathrm{C}$ bond lengths are $0.16-0.18 \AA$ longer than the $\mathrm{Co}-\mathrm{C}$ bond lengths, as is usually observed. ${ }^{58,59} \mathrm{The} \mathrm{Cd}$ atoms have octahedral coordination geometries. Atom $\mathrm{Cd} 1$ sits at a general position, while atom $\mathrm{Cd} 2$ is located on an inversion center. The $\mathrm{Cd}-\mathrm{N}$ (cyano) distances lie in the range 2.2878(16)2.4511(16) $\AA$, while the $\mathrm{Cd}-\mathrm{N}(\mathrm{tn})$ distances average 2.385(15) $\AA$, which is usual for six coordinated $\mathrm{CdN}_{6} .{ }^{52}$

Again the structure can be described as being formed of hexametallocycles consisting of only $\mathrm{Cd} 1$ atoms and tn ligands. They are connected via cyano bridges to form a three-dimensional network (Figure 4a). This time the cyano bridges involve penta-, tetra- and tris-metallocycles.

Topological analysis of compound $\mathbf{2}$ shows that the structure possesses a 3D extended framework constructed from four different nodes (Figure $4 b)$ with overall $\left(3^{1} 4^{3} 5^{4} 6^{6} 7\right)_{2}\left(3^{2} 4^{6} 5^{4} 6^{3}\right)$ $\left(3^{2} 4^{6} 5^{4} 6^{3}\right)\left(4^{2} 5^{2} 6^{2}\right)$ Schläfli symbol for the 6-connected Cd1, Cd2 and $\mathrm{Cr} 2$ and 4-connected $\mathrm{Cr} 1$ nodes, respectively. The environment of the topological nodes is shown in Figure S6 in the Supporting Information. The 6-connected $\mathrm{Cd} 2$ and $\mathrm{Cr} 2$ have the same Schläfli symbol.

Complex $\left(\left[\mathrm{Cu}_{2}(\mathrm{tn})_{2}\right]\left[\mathrm{Ru}(\mathrm{CN})_{6}\right] \cdot 4 \mathrm{H}_{2} \mathrm{O}\right)_{\infty}(3)$ is isostructural with the iron(II) analogue, ${ }^{60}$ and the structural features are similar to those of compounds $\mathbf{1}$ and $\mathbf{2}$. The asymmetric unit of 3 consists of half a $\left[\mathrm{Ru}(\mathrm{CN})_{6}\right]^{4-}$ anion, a $\left[\mathrm{Cu}(\mathrm{tn})_{2}\right]^{2+}$ cation, and two water molecules of crystallization (Figure 5), atom Ru1 being situated on an inversion center.

The $\mathrm{Ru}-\mathrm{C}$ and $\mathrm{C}-\mathrm{N}$ bond distances and $\mathrm{C}-\mathrm{Ru}-\mathrm{C}$ angles

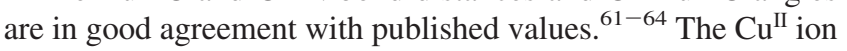
is penta-coordinated, bonding to two nitrogen atoms of two equivalent tn ligands (N4, N5), and to three nitrogen atoms of the cyano groups $(\mathrm{N} 1, \mathrm{~N} 2$ and $\mathrm{N} 3)$. The $\mathrm{N}-\mathrm{Cu}-\mathrm{N}$ angles in the pseudo base deviate strongly from ideal trigonal-bipyramidal geometry (Figure 6). Such a distortion can be quantified using the $\tau$ parameter, as defined by Addison et al. ( $\tau=1$ for trigonal bipyramidal and 0 for square pyramidal) ${ }^{65}$ The calculated value $\tau=0.57$ indicates the extremely high degree of distortion of the coordination polyhedron.

In this structure, the tn ligand is again acting as a bridging ligand. The ruthenium ion, which has an almost regular 
a

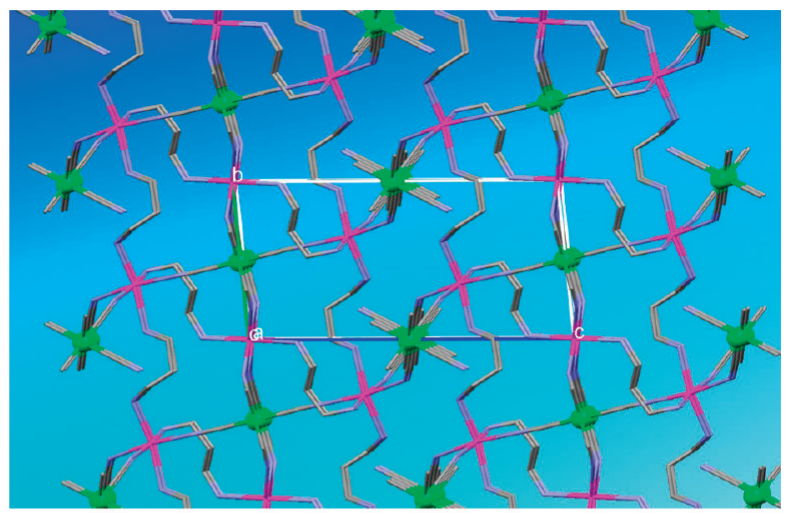

b

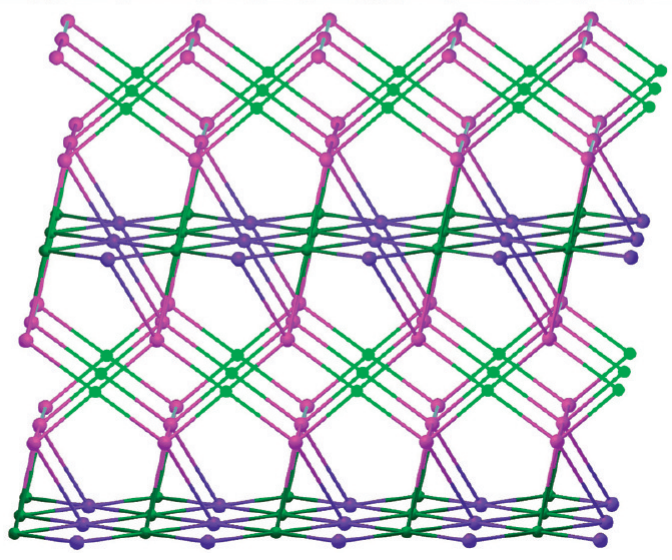

Figure 4. (a) View down the $a$ axis of the crystal packing in compound 2 (Cd, pink; $\mathrm{Cr}$, green). The $\mathrm{H}$ atoms have been omitted for clarity. (b) View along the crystallographic $b$ direction of a fragment of the topological network for compound $\mathbf{2}$. The $\mathrm{Cr} 1$ nodes are shown in light green; $\mathrm{Cr} 2$, dark green; $\mathrm{Cd} 1$, pink; $\mathrm{Cd} 2$, violet.

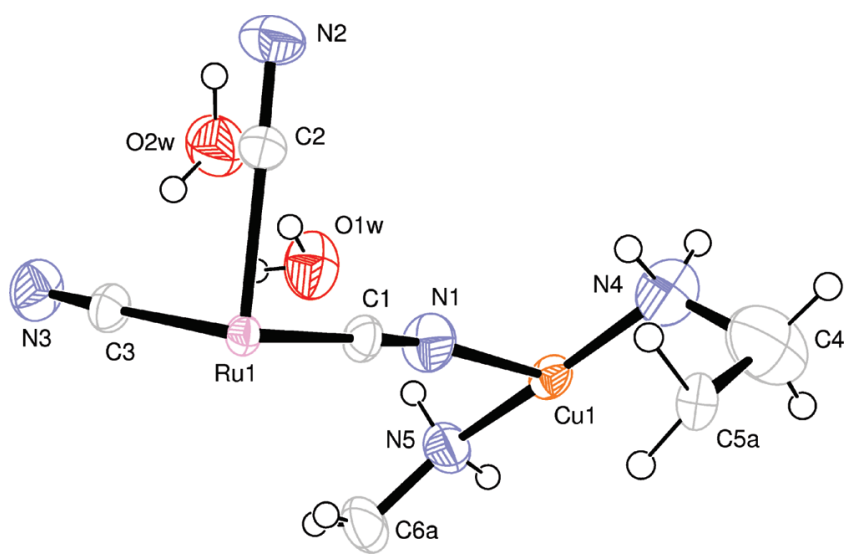

Figure 5. View of the asymmetric unit of the compound $\mathbf{3}$, showing the atom numbering scheme and displacement ellipsoids drawn at the $50 \%$ probability level. The disordered atoms of the tn ligand have been omitted for clarity.

octahedral geometry, is linked to six copper(II) ions by six cyanide bridges, while the copper ion is linked to three equivalent $\left[\mathrm{Ru}(\mathrm{CN})_{6}\right]^{4-}$ anions. This leads to the formation of a three-dimensional arrangement in which the $\mathrm{Ru}-\mathrm{C} \equiv \mathrm{N}$ units are essentially linear, while the $\mathrm{Cu}-\mathrm{N} \equiv \mathrm{C}$ bond angles vary between $149.7(7)$ and $176.1(8)^{\circ}$.

As shown in Figure 6a (bottom) the water molecules occupy channels (see also Figure S2 in the Supporting Information). They are involved in hydrogen bonding with the terminal $\mathrm{CN}$ groups and the $\mathrm{NH}_{2}$ groups of the tn ligands (Table $\mathrm{S} 2$ in the Supporting Information). The potential solvent volume of 174.3 a
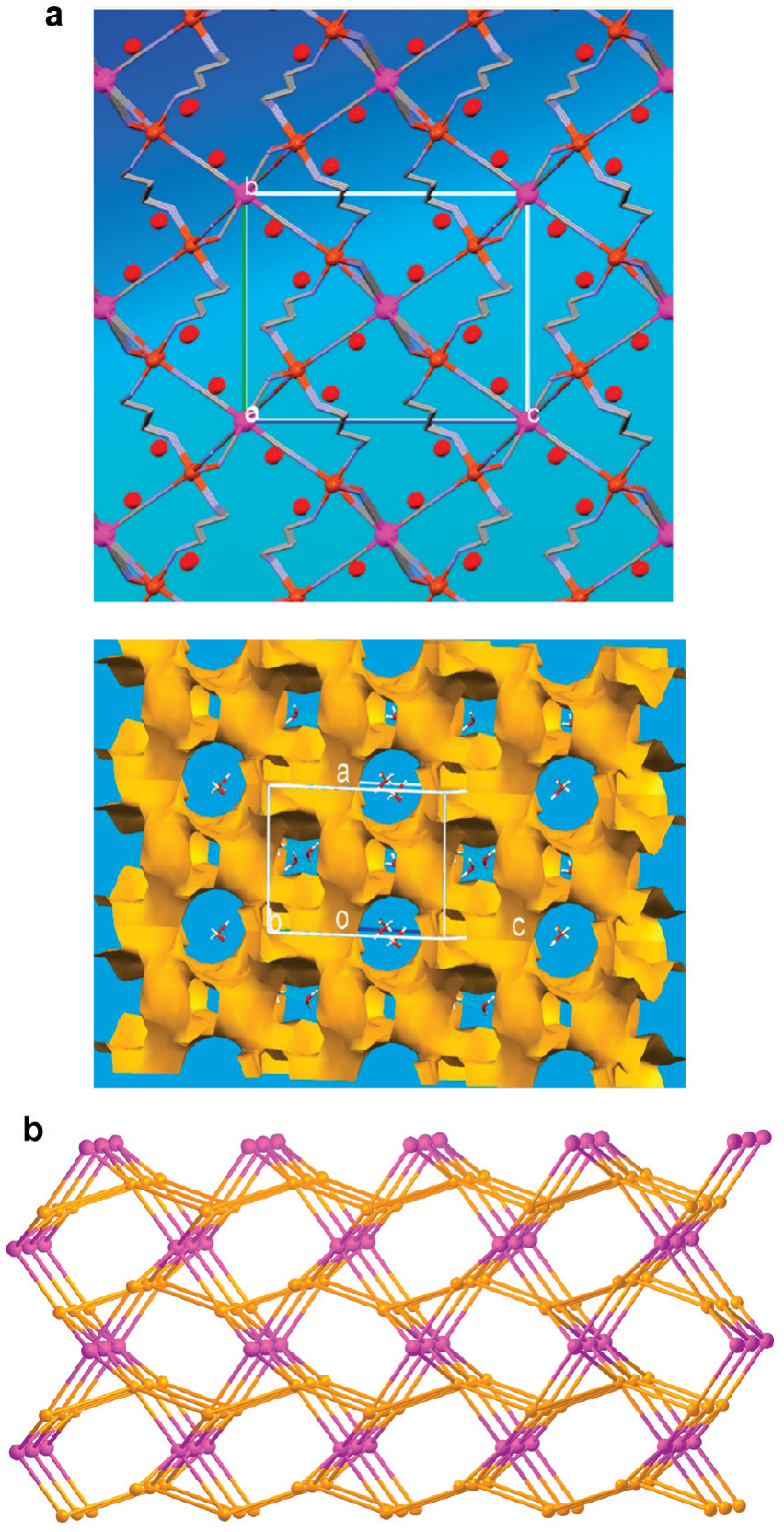

Figure 6. (a) Top: View along the $a$ axis of the structure of compound $3(\mathrm{Cu}$, orange; $\mathrm{Ru}$, pink), showing the hexa-metallocycles (The red balls represent water molecules. The $\mathrm{H}$ atoms have been omitted for clarity). Bottom: A view of the framework surface of compound 1 with the water molecules present in the channels. (b) View along the crystallographic $a$ axis of a fragment of the topological network of compound 3. The $\mathrm{Ru}$ nodes are shown in pink, $\mathrm{Cu}$ nodes in orange.

$\AA^{3}$, occupied by the water molecules of crystallization, accounts for $15.8 \%$ of the volume of the unit cell $\left(1102.4 \AA^{3}\right.$ ).

This structure can be described as being formed of hexametallocycles consisting of both tn and cyano bridges. They are further connected via cyano bridges to form a threedimensional network (Figure 6a). This time the supplementary cyano bridges involve tetra- and tris-metallocycles only.

The topological network of compound $\mathbf{3}$ (Figure $6 \mathrm{~b}$ ) consists of 6-connected $\mathrm{Ru}$ and 5-connected $\mathrm{Cu}$ nodes and has the $\left(3^{2} 4^{1} 5^{3} 6^{4}\right)_{2}\left(3^{2} 4^{2} 5^{6} 6^{2} 7^{3}\right)$ Schläfli symbol for the $\mathrm{Cu}$ and Ru nodes, respectively (Figure S7 in the Supporting Information).

IR Analysis. The infrared spectra of compounds 1, 2 and $\mathbf{3}$ exhibit the absorption bands expected for the tn ligand and the 
Table 2. Summary of the Immersion Calorimetry Experiments Performed on Compounds 1 and 3

\begin{tabular}{cccc}
\hline sample & outgassing conditions & liquid & $-\Delta_{\mathrm{i}} H$ (average) $\pm 3, \mathrm{~J} / \mathrm{g}$ \\
\hline $\mathbf{1}$ & $70{ }^{\circ} \mathrm{C}$ for $6 \mathrm{~h}$ & water & 32.4 \\
$\mathbf{3}$ & $75^{\circ} \mathrm{C}$ for $7 \mathrm{~h}$ & water & 28.8 \\
& $20{ }^{\circ} \mathrm{C}$ for $7 \mathrm{~h}$ & water & 47.8
\end{tabular}

hexacyanometalate counterions. The presence of the latter is clearly indicated by the strong absorption bands assignable to the $v(\mathrm{C} \equiv \mathrm{N})$ stretching vibrations in the range $2000-2200 \mathrm{~cm}^{-1}$. Coordination of the $\mathrm{CN}$ ligand to a second metal ion through its nitrogen atom results in a displacement to higher wavelengths. ${ }^{66}$ For 1 the shifts in the $v(\mathrm{CN})$ stretching frequencies are from $2135 \mathrm{~cm}^{-1}$ in $\mathrm{K}_{3}\left[\mathrm{Co}(\mathrm{CN})_{6}\right]^{67}$ to $2172 \mathrm{~cm}^{-1}$, and for 2 the shifts are from $2130 \mathrm{~cm}^{-1}$ in $\mathrm{K}_{3}\left[\mathrm{Cr}(\mathrm{CN})_{6}\right]^{67}$ to $2158 \mathrm{~cm}^{-1}$. This clearly indicates the assembly of a $\mathrm{Co}^{\mathrm{III}}-\mathrm{CN}-\mathrm{Cu}^{\mathrm{II}}$ bridge for 1 and a $\mathrm{Cr}$ III $-\mathrm{CN}-\mathrm{Cu}^{\mathrm{II}}$ bridge for 2 . The $v(\mathrm{C} \equiv \mathrm{N})$ stretching frequencies for $\mathbf{3}$ are found at $2095 \mathrm{~cm}^{-1}$, which is in good agreement with the presence of $\left[\mathrm{Ru}(\mathrm{CN})_{6}\right]^{4-}$ units having at least one terminal $\mathrm{CN}$ ligand. ${ }^{32,63}$ The 1,3-diaminopropane ligand is also characterized by the presence in the IR spectrum of bands due to the $v(\mathrm{NH})$ stretching vibrations of the $\mathrm{NH}_{2}$ groups, in the $3150-3350 \mathrm{~cm}^{-1}$ region, and to the $v(\mathrm{CH})$ stretching vibrations of the $\mathrm{CH}_{2}$ groups, in the $2800-2980 \mathrm{~cm}^{-1}$ region. ${ }^{68}$

Immersion Calorimetry and Heat of Structural Transformation. Immersion calorimetry is based on the determination of the enthalpy change occurring on immersing an outgassed nanoporous sample into a liquid; it is rapid to perform, sensitive and accurate. ${ }^{69}$ The enthalpy change is related to the chemical and structural nature of the surface, and the enthalpy of immersion, $-\Delta_{\mathrm{i}} H$, is equal to the integral of the net heat of adsorption. $^{70,71}$ The studies carried out with compounds $\mathbf{1}$ and 3 showed that they have similar behavior for the adsorption of water (Table 2). In both cases, for the samples outgassed at 70 ${ }^{\circ} \mathrm{C}(\mathbf{1})$ and $75{ }^{\circ} \mathrm{C} \mathrm{(3)}$, the heat of immersion is equivalent to the heat of filling of the nanopores plus the heat of the structural transformation.

It was possible to determine the heat of the structural transformation of compound $\mathbf{3}$ by outgassing a sample at 20 ${ }^{\circ} \mathrm{C}$ for $7 \mathrm{~h}$ under vacuum $\left(10^{-3}\right.$ Torr $)$, giving a final weight loss of $12 \%$. This procedure avoided any change in the structure of the compound on dehydration. The PXRD of this sample is indeed identical to that of the original compound 3 (Figure S3 in the Supporting Information). The heat of immersion of this sample gave the heat of filling of the nanopores alone, and was found to be higher than that for the sample outgassed at $75^{\circ} \mathrm{C}$ (Table 2). The latter corresponds to the heat of filling of the nanopores plus the heat of the structural transformation. Hence, the difference in $-\Delta_{\mathrm{i}} H$, i.e. ca. $19 \pm 3 \mathrm{~J} / \mathrm{g}$, corresponds to the heat of transformation of the structure. To verify this, a sample of compound 3 outgassed at $20^{\circ} \mathrm{C}$ was incubated at $25^{\circ} \mathrm{C}$ for DSC measurement (heating from 25 to $120^{\circ} \mathrm{C}$ at a rate of $10^{\circ}$ $\mathrm{min}^{-1}$ ). One endothermic effect of $21 \mathrm{~J} / \mathrm{g}$ was observed. This value agrees well with the value expected from immersion calorimetry, that is, ca. $19 \pm 3 \mathrm{~J} / \mathrm{g}$. The PXRD pattern of the sample after DSC corresponds to the PXRD pattern of $\mathbf{3}$ after TGA analysis (Figure S3 in the Supporting Information), indicating that on heating the change in the crystal structure had taken place. To the best of our knowledge this is the first time that the heat of a structural transformation has been demonstrated by two different methods. Unfortunately it was not possible to carry out the same analysis for compound $\mathbf{1}$, as it already transforms to the dry form (weight loss of $7.85 \%$ ) on outgassing at $20^{\circ} \mathrm{C}$.

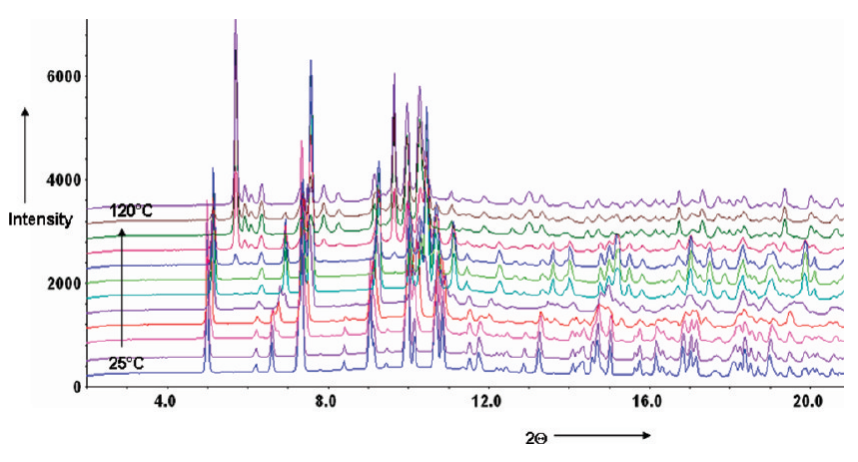

Figure 7. In situ synchrotron powder X-ray diffraction (PXRD) patterns obtained on heating compound $\mathbf{3}$ from 25 to $120^{\circ} \mathrm{C}$.

Thermal Analyses, DSC and Powder X-ray Diffraction. The thermal stability of the water solvated compounds $\mathbf{1}$ and $\mathbf{3}$ was studied by thermogravimetric analysis (TGA) (Figure S4 in the Supporting Information) and differential scanning calorimetry (DSC) (Figure S5 in the Supporting Information). TGA for $\mathbf{1}$ indicates that the water molecules are completely removed at $130{ }^{\circ} \mathrm{C}$ in one step. There is a weight loss of $7.79 \%$ in the temperature range $25-125^{\circ} \mathrm{C}$, corresponding to the loss of five water molecules (theoretical value $7.78 \%$ ). The TG curve for compound $\mathbf{3}$ clearly shows two steps in the weight loss. The first step is at ca. $60{ }^{\circ} \mathrm{C}$ with a weight loss of $6.10 \%$, which correspond to two molecules of water (theoretical 5.9\%). A final plateau is reached at ca. $85{ }^{\circ} \mathrm{C}$ with a weight loss of $6.04 \%$. The total weight loss of $12.14 \%$ corresponds to the loss of four water molecules (theoretical value is $11.75 \%$ ). The lability of the water molecules was shown by DSC measurements. The samples were incubated at $20{ }^{\circ} \mathrm{C}$ followed by heating at a rate of $10^{\circ} \mathrm{min}^{-1}$ to $100{ }^{\circ} \mathrm{C}$. For compound 1 one endothermic effect of $113 \mathrm{~J} / \mathrm{g}$ was observed at $95.4{ }^{\circ} \mathrm{C}$, and for complex $\mathbf{3}$ one endothermic effect of $131 \mathrm{~J} / \mathrm{g}$ was observed at $73.5^{\circ} \mathrm{C}$.

Some unique and intriguing phenomena were observed by in situ synchrotron powder X-ray diffraction (PXRD) measurements upon heating compound $\mathbf{3}$ (Figure 7). A capillary containing a powdered sample of $\mathbf{3}$ was slowly heated to 120 ${ }^{\circ} \mathrm{C}$. There is a gradual change in the powder diffractogram from 25 to $65^{\circ} \mathrm{C}$, which is probably due to a slow loss of water molecules and shrinking of the unit cell. At $105{ }^{\circ} \mathrm{C}$ there is a definite change in the diffractogram, for example the intense peak at ca. $5^{\circ}$ in $2 \theta$, observable from 25 to $95{ }^{\circ} \mathrm{C}$, has disappeared and a new intense peak appears at ca. $5.8^{\circ}$ in $2 \theta$. Finally, at $120{ }^{\circ} \mathrm{C}$ the diffractogram is identical to that of the sample recuperated after TGA, see Figure $9 \mathrm{~b}$. The structure of this new phase is unknown at present.

An interesting reversible structural transformation involving a crystalline, and not so highly crystalline state (after TG), was observed for compound $\mathbf{1}$ (Figure 8). The reversibility of this process was confirmed by PXRD measurements (Figures 8c and 8d). A capillary containing a powdered sample of $\mathbf{1}$ after TG (Figure $8 \mathrm{~b}$ ) was immersed into water for $90 \mathrm{~min}$. The PXRD was then remeasured (Figure 8c), and it was found that the peak positions and intensities were identical with those observed for the single crystal of $\mathbf{1}$ (Figure 8a). Therefore, complex 1 exhibits "spongelike" molecular properties: it can easily take up water molecules and return to the original structure. It was possible to repeat this process a number of times without any loss of the crystallinity of $\mathbf{1}$ (Figure 8d).

The same "spongelike" behavior was also found for complex 3. Figure 9a shows the PXRD pattern of $\mathbf{3}$ before heating. After heating to $120{ }^{\circ} \mathrm{C}$ under an inert atmosphere, all four water 


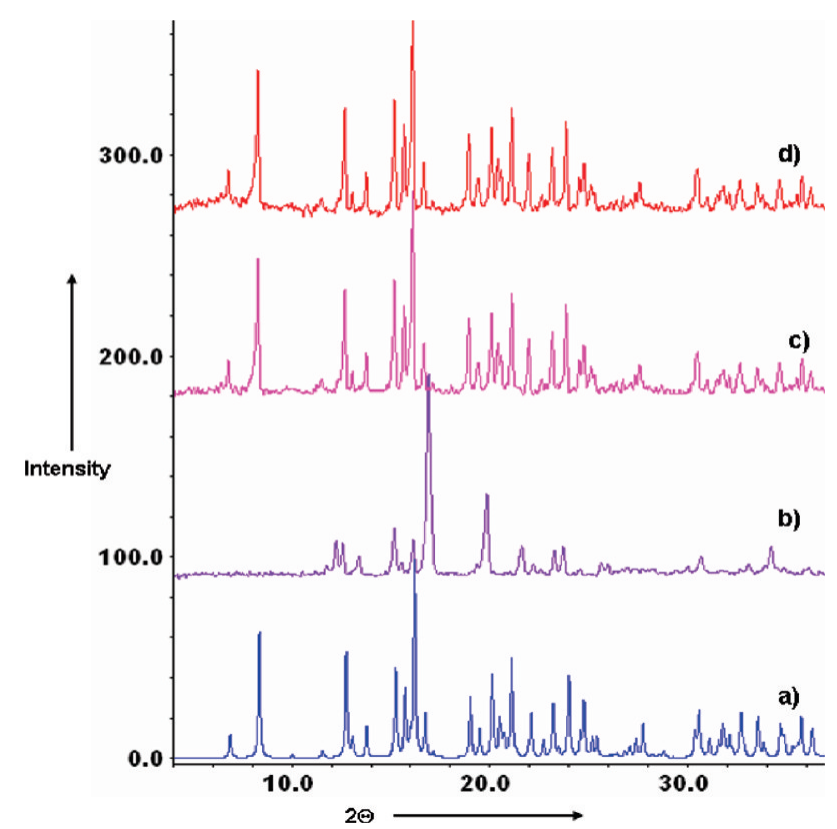

Figure 8. PXRD patterns for (a) a single-phase polycrystalline sample of 1; (b) sample after being heated to $140{ }^{\circ} \mathrm{C}$, at which point all five water molecules are lost; (c) sample from trace b after being placed in water for $90 \mathrm{~min}$; and (d) sample after repeating the above procedure $[\mathrm{a} \rightarrow \mathrm{b} \rightarrow \mathrm{c} / \mathrm{a}]$ at least three times.

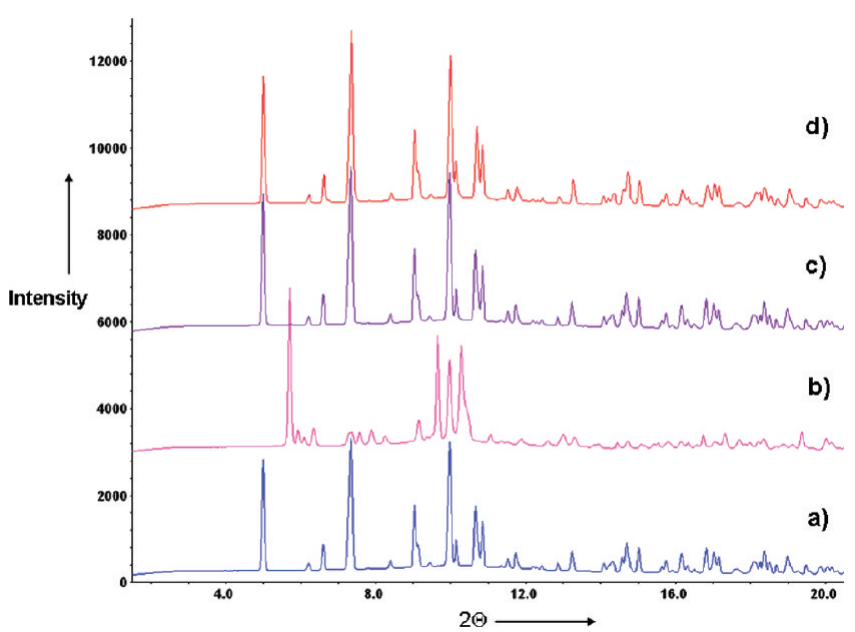

Figure 9. PXRD patterns for (a) a single-phase polycrystalline sample of 3; (b) sample after being heated to $120{ }^{\circ} \mathrm{C}$, at which point all four water molecules are lost and the sample color changed (from lightgreen to dark-green); (c) sample from trace b after being placed in water for $30 \mathrm{~min}$ (the color turned back to light-green); and (d) sample after repeating the above procedure $[\mathrm{a} \rightarrow \mathrm{b} \rightarrow \mathrm{c} / \mathrm{a}]$ at least four times.

molecules were removed and the color of the sample changed from the original light-green to dark-green. The PXRD pattern taken at this point is shown in Figure $9 \mathrm{~b}$ and clearly indicates that a change in the crystal structure had taken place.

In the IR spectrum of the dried sample there is no absorption band at $\sim 3537 \mathrm{~cm}^{-1}$, which corresponds to the vibration of the water $\mathrm{O}-\mathrm{H}$ bonds. This is in full agreement with the observation of the loss of the water molecules after TGA. The results of the elemental analysis for this dried sample (found $\mathrm{C}, 27.39$; $\mathrm{H}, 3.93 ; \mathrm{N}, 26.86 . \mathrm{C}_{12} \mathrm{H}_{20} \mathrm{~N}_{10} \mathrm{Cu}_{2} \mathrm{Ru}_{1}$ requires $\mathrm{C}, 27.07 ; \mathrm{H}, 3.79$; $\mathrm{N}, 26.30 \%$ ) confirmed the loss of all four water molecules. This dried sample was then placed in water for $30 \mathrm{~min}$. The color turned from dark-green to the original light-green, and the powder pattern taken at this stage (Figure 9c) is in excellent agreement with the original one, Figure 9a. The IR spectrum of this "wet" sample showed the reappearance of a strong band at $3537 \mathrm{~cm}^{-1}$, indicative of the presence of water molecules in the structure. This reversible structural transformation process associated with a color change was repeated a number of times. Figure $9 \mathrm{~d}$ is the PXRD pattern taken after the same procedure had been repeated four times on the original sample.

\section{Conclusion}

Three bimetallic cyano-bridged framework materials have been made in a very simple manner from inexpensive starting materials. Compounds $\left(\left(\left[\mathrm{Cd}_{3}(\mathrm{tn})_{4}\right]\left[\mathrm{Co}(\mathrm{CN})_{6}\right]_{2}\right) \cdot 5 \mathrm{H}_{2} \mathrm{O}\right)_{\infty}(\mathbf{1})$, $\left([\mathrm{Cd}(\mathrm{tn})]_{3}[\mathrm{Cr}-\right.$ $\left.\left.(\mathrm{CN})_{6}\right]_{2}\right)_{\infty}(2)$, and $\left(\left[\mathrm{Cu}_{2}(\mathrm{tn})_{2}\right]\left[\mathrm{Ru}(\mathrm{CN})_{6}\right] \cdot 4 \mathrm{H}_{2} \mathrm{O}\right)_{\infty}(\mathbf{3})$ have been synthesized using a common organic ligand, 1,3-diaminopropane, a potassium hexacyanometalate and a transition metal salt. These new materials have been fully characterized and shown to have 3D framework structures. Compounds $\mathbf{1}$ and $\mathbf{3}$ have cavities and channels occupied by water molecules of crystallization and show "spongelike" dynamic behavior triggered by guest removal and inclusion. It was shown by immersion calorimetry and in situ powder X-ray diffraction that the dehydration/rehydration processes, which involve changes in the structures of $\mathbf{1}$ and $\mathbf{3}$, are reversible. The heat of the structural transformation on rehydration of $\mathbf{3}$ was found to be ca. $19 \pm 3 \mathrm{~J} / \mathrm{g}$. Work is in progress to understand how these structural transformations take place. Further gas/solid and liquid/solid adsorption studies, and in situ X-ray diffraction studies, involving both water and other solvents, are currently in progress.

Acknowledgment. This work was financed by the Swiss National Science Foundation (Grant No. 20-111738). We are also grateful to the Swiss-Norwegian Beamlines for the provision of synchrotron beam time.

Supporting Information Available: Additional figures and tables including crystal packing in $\mathbf{1}$ and $\mathbf{3}$, PXRD for $\mathbf{3}$, TG and DSC curves of $\mathbf{1}$ and $\mathbf{3}$, topological analysis for $\mathbf{1 - 3}$, and hydrogen bonding in $\mathbf{1}$ and 3. This material is available free of charge via the Internet at http:// pubs.acs.org.

\section{References}

(1) Batten, S. R. Neville, S. M. Turner, D. Coordination Polymers: Design, Analysis and Application; Royal Society of Chemistry: 2009; Vol. 1.

(2) Tranchemontagne, D. J.; Ni, Z.; O'Keeffe, M.; Yaghi, O. M. Angew. Chem., Int. Ed. 2008, 47 (28), 5136.

(3) Ferey, G. Stud. Surf. Sci. Catal. 2007, 170A, 66.

(4) Maji, T. K.; Kitagawa, S. Pure Appl. Chem. 2007, 79 (12), 2155.

(5) Kubota, Y.; Takata, M.; Kobayashi, T. C.; Kitagawa, S. Coord. Chem. Rev. 2007, 251 (21-24), 2510.

(6) Serre, C.; Mellot-Draznieks, C.; Surblé, S.; Audebrand, N.; Filinchuk, Y.; Férey, G. Science 2007, 1828.

(7) Rowsell, J. L. C.; Yaghi, O. M. Microporous Mesopourous Mater. 2004, $73(1-2), 3-14$.

(8) Rosi, N. L.; Eddaoudi, M.; Kim, J.; O’Keeffe, M.; Yaghi, O. M. CrystEngComm 2002, 4, 401.

(9) Kitagawa, S.; Kitaura, R.; Noro, S.-I. Angew. Chem. 2004, 116, 2388.

(10) Moulton, B.; Zaworotko, M. Chem. Rev. 2001, 101, 1629.

(11) Eddaoudi, M.; Moler, D. B.; Li, H.; Chen, B.; Reineke, T. M.; O'Keeffe, M.; Yaghi, O. M. Acc. Chem. Res. 2001, 34, 319.

(12) Fujita, M.; Know, Y. J.; Washizu, S.; Ogura, K. J. Am. Chem. Soc. 1994, 116, 1151.

(13) Millange, F.; Serre, C.; Guillou, N.; Ferey, G.; Walton, R. I. Angew. Chem., Int. Ed. 2008, 47, 4100.

(14) Ferey, G. Chem. Soc. Rev. 2008, 37 (1), 191.

(15) Maji, T. K.; Kitagawa, S. Pure Appl. Chem. 2007, 79 (12), 2155.

(16) Latroche, M.; Suble, S.; Serre, C.; Mellot-Draznieks, C.; Llewellyn, P. L.; Lee, J.-H.; Chang, J.-S.; Jhung, S. H.; Ferey, G. Angew. Chem., Int. Ed. 2006, 45, 8227. 
(17) Llewellyn, P. L.; Maurin, G.; Devic, T.; Loera-Serna, S.; Rosenbach, N.; Serre, C.; Bourrelly, S.; Horcajada, P.; Filinchuk, Y.; Férey, G. J. Am. Chem. Soc. 2008, 130, 12808.

(18) Banerjee, R.; Phan, A.; Wang, B.; Knobler, C.; Furukawa, H.; O'Keeffe, M.; Yaghi, O. M. Science 2008, 319 (5865), 939.

(19) Xue, M.; Zhu, G.; Ding, H.; Wu, L.; Zhao, X.; Jin, Z.; Qiu, S. Cryst. Growth Des. 2009, 9 (3), 1481.

(20) Galli, S.; Masciocchi, N.; Tagliabue, G.; Sironi, A.; Navarro, J. A. R.; Salas, J. M.; Mendez-Linan, L.; Domingo, M.; Perez-Mendoza, M.; Barea, E. Chem.-Eur. J. 2008, 14, 9890.

(21) Mueller U. Schubert, M. M. Yaghi, O. M. Handbook of Heterogeneous Catalysis, 2nd Ed.; Wiley-VCH Verlag GmbH \& Co. KGaA: Weinheim, Germany, 2008; Vol. 1, pp 247-262.

(22) Rowsell, J. L.; Yaghi, O. M. Angew. Chem., Int. Ed. 2004, 44 (30), 4670.

(23) Choi, J. Y.; Jeo Kim, J.; Furukawa, H.; Chae, H. K. Chem. Lett. 2006, 35,1054

(24) Li, H.; Eddaoudi, M.; O’Keeffe, M.; Yaghi, O. M. Nature 1999, 402, 276.

(25) Yaghi, O. M.; O’Keeffe, M.; Ockwig, N. W.; Chae, H. K.; Eddaoudi, M.; Kim, J. Nature 2003, 423, 705.

(26) Chae, H. K.; Siberio-Perez, D. Y.; Kim, J.; Go, Y.-B.; Eddaoudi, M.; Matzger, A. J.; O'Keeffe, M.; Yaghi, O. M. Nature 2004, 427, 523.

(27) Dybtsev, D. N.; Chun, H.; Yoon, S. H.; Kim, D.; Kim, K. J. Am. Chem. Soc. 2004, 126, 32.

(28) Serre, C.; Surble, S.; Mellot-Draznieks, C.; Filinchuk, Y.; Ferey, G. Dalton Trans. 2008, 5462.

(29) Ohba, M.; Fukita, N.; Okawa, H. J. Am. Chem. Soc. 1997, 119, 1011.

(30) Miyasaka, H.; Matsumoto, N.; Okawa, H.; Re, N.; Gallo, E.; Floriani, C. J. Am. Chem. Soc. 1996, 118, 981.

(31) Coronado, E.; Gimenez-Saiz, C.; Martinez-Agudo, J. M.; Nuez, A.; Romero, F. M.; Stoeckli-Evans, H. Polyhedron 2003, 22, 2435.

(32) Shek, I. P.-Y.; Yeung, W.-F.; Lau, T.-C.; Zhang, J.; Gao, S.; Szeto, L.; Wong, W.-T. Eur. J. Inorg. Chem. 2005, 364.

(33) Zhoua, H.; Chena, Y.-Y.; Yuana, A.-H.; Shenb, X.-P. Inorg. Chem. Commun. 2008, 11, 363.

(34) Agusti, G.; Munoz, M. C.; Gaspar, A. B.; Real, J. A. Inorg. Chem. 2009, 48 (8), 3371.

(35) Beauvais, L. G.; Long, J. R. J. Am. Chem. Soc. 2002, 124, 12096.

(36) Pretsch, T.; Chapman, K. W.; Halder, g. J.; Kepert, C. J. Chem. Commun. 2006, 1857.

(37) Chapman, K. W.; Chupas, P. J.; Kepert, C. J. J. Am. Chem. Soc. 2006, $128,7009$.

(38) Galli, S.; Masciocchi, N.; Tagliabue, G.; Sironi, A.; Navarro, J. A. R.; Salas, J. M.; Mendez-Linan, L.; Domingo, M.; Perez-Mendoza, M.; Barea, E. Chem.-Eur. J. 2008, 14, 9890.

(39) Bauer, S.; Marrot, J.; Devic, T.; Férey, G.; Stock, N. Inorg. Chem. 2007, 46, 9998.

(40) Maji, T. K.; Mostafa, G.; Matsuda, R.; Kitagawa, S. J. Am. Chem. Soc. 2005, 127 (49), 17152

(41) Iremonger, S. S.; Southon, P. D.; Kepert, C. J. Dalton Trans. 2008, 44,6103
(42) Sereda, O.; Ribas, J.; Stoeckli-Evans, H. Inorg. Chem. 2008, 47 (12), 5107.

(43) Sereda, O.; Stoeckli-Evans, H. Acta Crystallogr. 2008, C64 (6), m221.

(44) Sereda, O.; Neels, A.; Stoeckli, F.; Stoeckli-Evans, H.; Filinchuk, Y. Cryst. Growth. Des. 2008, 8 (7), 2307.

(45) Bansal, R. C. Donnet, J. B. Stoeckli, F. Active Carbon; Marcel Dekker: New York, 1988.

(46) Stoeckli, F.; Hugi-Cleary, D.; Centeno, T. A. J. Eur. Ceram. Soc. 1998 , $18,1177$.

(47) Stoe \& Cie. IPDS-2 Software; Stoe \& Cie GmbH: Darmstadt, Germany, 2006.

(48) Sheldrick, G. M. Acta Crystallogr. 2008, A64, 112.

(49) Dolomanov, O. V.; Blake, A. J.; Champness, N. R.; Schröder, M. J. Appl. Crystallogr. 2003, 36, 1283.

(50) Wolfel, E. R. J. Appl. Crystallogr. 1981, 14, 291.

(51) Wolfel, E. R. J. Appl. Crystallogr. 1983, 16, 341.

(52) Yuge, H.; Mamada, A.; Asai, M.; Nishikiori, S.; Iwamoto, T. Dalton Trans. 1995, 3195.

(53) Marvaud, V.; Decroix, C.; Scuiller, A.; Guyard-Duhayon, C.; Vaissermann, J.; Gonnet, F.; Verdaguer, M. Chem.-Eur. J. 2003, 9, 1677.

(54) Eckhardt, R.; Hanika-Heidl, H.; Fischer, R. D. Chem.-Eur. J. 2003, 9, 1795 .

(55) Wells, A. F. Three Dimensional Nets and Polyhedra; John Wiley \& Sons: New York, 1977.

(56) Wells, A. F. Further Studies of Three-Dimensional Nets; ACA Monograph No. 8; American Crystallographic Association: 1979.

(57) Spek, A. L. J. Appl. Crystallogr. 2003, 36, 7.

(58) Kohn, J. A.; Townes, W. D. Acta Crystallogr. 1961, 14, 617.

(59) Jagner, S.; Ljungstrom, E.; Vannerberg, N.-G. Acta Chem. Scand., Ser. A 1974, 28, 623.

(60) Triki, S.; Sala-Pala, J.; Thétiot, F.; Gomes-Garcia, C. J.; Daran, J.-C. Eur. J. Inorg. Chem. 2006, 185.

(61) Mullica, D. F.; Hayward, P. K.; Sappenfield, E. L. Inorg. Chim. Acta 1995, 237, 111.

(62) Mullica, D. F.; Hayward, P. K.; Sappenfield, E. L. Inorg. Chim. Acta 1996, 253, 97.

(63) Rüegg, M.; Ludi, A.; Rieder, K. Inorg. Chem. 1971, 10, 1773.

(64) Mullica, D. F.; Sappenfield, E. L. Inorg. Chim. Acta 1997, 258, 101.

(65) Addison, A. W.; Rao, T. N.; Reedijk, J.; van Rijn, J.; Verschoor, G. J. Chem. Soc., Dalton Trans. 1984, 7, 1349.

(66) Nakamoto, K. Infrared and Raman Spectra of Inorganic and coordination Compounds, 3rd ed.; Wiley: New York, 1978.

(67) Uehara, A.; Terabe, S.; Tsuchiya, R. Inorg. Chem. 1983, 22, 2864.

(68) Mondal, N.; Saha, M. K.; Bag, B.; Mitra, S.; Gramlich, V.; Ribas, J.; Fallah, M. S. E. J. Chem. Soc., Dalton Trans. 2000, 1601.

(69) IUPAC Recommendations. Pure Appl. Chem., 66, 1994.

(70) Stoeckli, F. Adsorpt. Sci. Technol. 1993, 11, 3.

(71) Stoeckli, F.; Hugi-Cleary, D.; Centeno, T. A. J. Eur. Ceram. Soc. 1998, $18,1177$.

CG800883X 